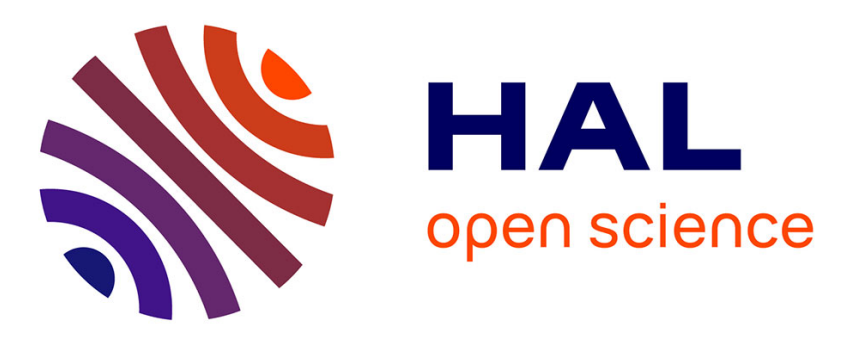

\title{
Higher structural connectivity and resistance against invasions of soil bioengineering over hard-engineering for riverbank stabilisation
}

François-Marie Martin, Philippe Janssen, L. Bergès, Blandine Dupont, André Evette

\section{- To cite this version:}

François-Marie Martin, Philippe Janssen, L. Bergès, Blandine Dupont, André Evette. Higher structural connectivity and resistance against invasions of soil bioengineering over hard-engineering for riverbank stabilisation. Wetlands Ecology and Management, 2021, 29 (1), pp.27-39. 10.1007/s11273020-09765-6 . hal-03130649

\section{HAL Id: hal-03130649 \\ https://hal.science/hal-03130649}

Submitted on 3 Feb 2021

HAL is a multi-disciplinary open access archive for the deposit and dissemination of scientific research documents, whether they are published or not. The documents may come from teaching and research institutions in France or abroad, or from public or private research centers.
L'archive ouverte pluridisciplinaire HAL, est destinée au dépôt et à la diffusion de documents scientifiques de niveau recherche, publiés ou non, émanant des établissements d'enseignement et de recherche français ou étrangers, des laboratoires publics ou privés. 


\title{
Higher structural connectivity and resistance against invasions of soil bioengineering over hard-engineering for riverbank stabilisation
}

François-Marie Martin ${ }^{1 *}$, Philippe Janssen ${ }^{1}$, Laurent Bergès ${ }^{1}$, Blandine Dupont ${ }^{1}$, André Evette ${ }^{1}$

${ }^{1}$ Univ. Grenoble Alpes, INRAE, LESSEM, 38400 Saint-Martin-d'Hères, France.

* Corresponding author: francois-marie.martin@inrae.fr

ORCID numbers: FM.Martin (0000-0002-2005-5098); P.Janssen (0000-0003-3310-0078); L.Bergès (0000-0003-0408-7900); B.Dupont (not available); A.Evette (0000-0002-0927-0037).

\begin{abstract}
Riparian corridors play an important role for the maintenance of regional biodiversity and ecosystem functions. Riparian forests are even the only semi-natural vegetation strips remaining in many agricultural or urbanised landscapes. In such landscapes, the spatial continuity of riparian vegetation is frequently broken by the construction of stabilisation structures engineered for erosion control. Here, we examined the effects of different riverbank stabilisation structures fascines (soil bioengineering), ripraps (hard engineering), and mixed-technique (lower-bank ripraps with upper-bank plantings) - on the structural connectivity of their respective riverbanks. We first revisited previously studied stabilisation structures to extend their vegetation sampling to their adjacent riverbanks. Then, for each type of stabilisation structure, we compared community composition, richness and abundance of native and invasive alien species (IAS), and cover of vegetation strata (herbaceous, shrub and tree) between stabilised embankments and their upstream and downstream banks. Results indicated that, although the composition of fascine banks differed from that of their adjacent riverbanks, they fitted nicely in the structural continuity of their riparian surroundings. Differences were likely explained by the proportion of fast-growing woody species (e.g. willows) planted in fascines, which also induced strong reductions in IAS richness and abundances; i.e. propagule "sinks". Conversely, ripraps broke the structural continuity of riverbanks and were heavily dominated by IAS while mixed-technique banks displayed intermediate characteristics. Consequently, we argued that fascines may be the riverbank stabilisation structures displaying highest ecological benefits in terms of habitat quality and connectivity and should be preferred over the other investigated engineering techniques.
\end{abstract}

Keywords: longitudinal connectivity; riparian vegetation; forest corridor; plant invasions; biotic resistance; riverine landscape management

\section{Declarations}

Funding: This work was part of a project (Trame bleue : espaces et continuités) funded by the European Union through the ERDF, the Auvergne-Rhône-Alpes region and the Agence de l'Eau Rhône-Méditerranée-Corse.

Conflict of Interest: The authors declare that they have no conflict of interest.

Availability of data: The datasets used in this study will be deposited in a public repository upon acceptance of a final version of this manuscript. 
Code availability: The R scripts used in this study will be available online upon acceptance of a final version of this manuscript.

\section{Introduction}

At the interface between aquatic and terrestrial ecosystems, riparian zones are landscape elements with disproportional ecological, recreational and aesthetic importance (Naiman \& Decamps, 1997; González et al., 2017). Although they only represent $1.4 \%$ of continental land surfaces, riparian zones and related floodplains contribute to more than $25 \%$ of all terrestrial ecosystem services (Tockner \& Stanford, 2002). Under natural conditions, rivers and their riparian areas are disturbance-dependent dynamic systems that are longitudinally, laterally and vertically linked by hydrogeomorphological processes occurring in spatiotemporal hierarchies (Ward \& Stanford, 1995; Tabacchi et al., 1998). The freedom space required by such dynamic systems to function properly is however often in conflict with human activities. This is why, despite their paramount importance, riverine ecosystems have undergone a very long history of human modifications (Evette et al., 2009) and are therefore highly degraded and threatened worldwide (Tockner \& Stanford, 2002; Dudgeon et al., 2006; González et al., 2017; Tonkin et al., 2018).

Flow regulation by dams and channel stabilisation by dikes are among the various anthropogenic pressures that alter the functionality of riparian zones (Best, 2019). By nature, these heavy civil engineering infrastructures alter flow, sediment and disturbance regimes, and lead to the degradation, loss or fragmentation of natural riparian habitats. As such, these constructions are directly and indirectly responsible of strong reductions in biodiversity and ecosystem functions over space and time (Ward \& Stanford, 1995; Dudgeon et al., 2006). By modifying the structure and composition of native riparian communities, they also favour the establishment and spread of invasive alien plant species (hereafter, IAS) in riparian corridors (Tickner et al., 2001; Pyšek et al., 2010). Overall, these cumulative changes in both abiotic and biotic conditions may lead to catastrophic shifts in ecosystems properties (Scheffer et al., 2001), therefore compromising efforts to restore riparian vegetation (Richardson et al., 2007).

When riverbanks need to be stabilised to protect human stakes from erosion, "hard" civil engineering techniques like ripraps or concrete walls are often chosen. Still, the use of naturebased solutions such as soil bioengineering techniques (e.g. fascines or vegetated crib-walls) is increasingly promoted (Li \& Eddleman, 2002; von der Thannen et al., 2017). Soil bioengineering seeks to mimic the natural functioning of riparian vegetation, i.e. strengthening riverbanks through the use of the soil fixation properties of roots and protecting the soil via a carpet effect as well as by slowing down water flow (Li \& Eddleman, 2002; Lavaine et al., 2015). Recently, several studies have demonstrated the effectiveness of soil bioengineering structures in resisting shear stress (e.g. Pinto et al., 2019; Recking et al., 2019) as well as their ecological benefits for riparian biodiversity (e.g. Cavaillé et al., 2015; Janssen et al., 2019). Nevertheless, as far as we know, no study has yet assessed the ecological benefits of these stabilisation techniques on the structural connectivity of riparian habitats, including the effects on the continuity of IAS populations. This information is yet essential to help stakeholders and river managers choose the engineering structure that will best fulfil the various functions associated with embankments (e.g. consolidation, restoration, recreation).

Connectivity is basically the degree to which the landscape facilitates or impedes species movements among habitat patches (Taylor et al., 1993). Two types of connectivity are usually distinguished: (i) functional connectivity, which refers to the behavioural responses of dispersing 
individuals to landscape structure and elements; and (ii) structural connectivity, which is related to the continuity and spatial arrangement of habitat patches in the landscape, independently of species attributes (Tischendorf \& Fahrig, 2000; Baguette \& Van Dyck, 2007). Obviously, although a structural connection may exist between habitat patches (i.e. a corridor), it does not necessarily mean that it is functional and thus used by all species (Beier et al., 2008). Nonetheless, the spatial continuity of habitats is recognized as of prime importance for the control of gene and individual fluxes and is therefore crucial for the maintenance of populations and metapopulations (Taylor et al., 1993; Mitchell et al., 2013). As such, the overwhelming importance of riparian zones in supporting regional biodiversity and ecosystem functions is, to a large extent, linked to their role as habitats and dispersal corridors (Naiman et al., 1993; Tabacchi et al., 1998; Van Looy et al., 2006). Around $70 \%$ of vertebrate species use riparian corridors at some point of their life-cycle (Raedeke, 1989 cited in Naiman et al., 1993), and evidence is piling up on the role of the spatial continuity of riparian forest in maintaining the dispersal dynamics of many species groups (e.g. Lambeets et al., 2009; Golfieri et al., 2018). This is especially relevant when we consider that riparian forests account for much of the remnant forests in many transformed landscapes (Lees \& Peres, 2008; Fremier et al., 2015).

Considering that, (i) the construction of engineered embankments on riverbanks leads to severe alterations of the structure of riparian habitats and impacts species whose movements are dependent on riparian connectivity and that, (ii) the time required for plant communities to recover and for the continuity of riparian vegetation to be restored varies with the local context but also with the level of revegetation of embankments (Tisserand et al., 2020), we expect a strong influence of the characteristics of stabilisation techniques on connectivity. By revisiting several engineered riverbanks which were used to study the direct effect of structures' type on riparian biodiversity and habitat quality (Cavaillé et al., 2013; Cavaillé et al., 2015; Janssen et al., 2019), we aimed to assess the relative effect of civil engineering and soil bioengineering structures on the structural connectivity of their respective local riverbanks. Specifically, we focused on three sets of engineered embankments - willow fascines (pure soil bioengineering), mixed-technique embankments (lower-bank ripraps with upper-bank plantings), and ripraps (pure civil engineering) - to answer the following questions: (1) do stabilisation structures break the floristic continuity of communities along riparian corridors at the local scale? (2) Do they affect patterns of native and IAS diversity? And (3) do they break the structural continuity of vegetation strata? These questions relate to different components of structural connectivity relevant for the dispersal dynamics of riparian plant and animal species. As such, they may help enlighten stakeholders and managers regarding the ecological impacts and benefits of stabilisation structures and may help improve the management of riparian ecosystems.

\section{Materials \& Methods}

Study area and sampling design

To investigate the effects of stabilisation engineering structures on the structural connectivity of riverbanks, we developed a dedicated sampling design. In the summer 2017, we sampled 15 riverbank sites spread across the Rhône-Alpes region in central-eastern France. Sites hosted either willow fascines $(n=5)$, mixed-technique embankments (i.e., lower-bank riprap combined with soil bioengineering on the upper parts of the bank; $n=5)$ or ripraps $(n=5)$. For a given site, we collected data at the level of the engineered embankment (e.g. riprap) as well as on its adjacent riverbanks, i.e. upstream and downstream. A site therefore encompassed three sampling areas, 
hereafter referred to as: the upstream bank, the structure's bank, and the downstream bank (Figure 1). At the scale of each study site, we gathered information on various environmental variables and, at the scale of each sampling area, we measured bank steepness and sampled plant communities (see following sections).

To the best of our abilities, we tried to select sites that shared similar environment and position to obtain comparable situations, especially regarding species pools. Consequently, all sites were located in densely populated areas, along rivers running in plains or large valleys, between 160 and $510 \mathrm{~m}$ a.s.l., and in globally similar climatic areas. To be selected, sites had to host structures with a minimal length of $50 \mathrm{~m}$ in order to avoid strong edge-effects in samples (Figure 1). Because we wanted the plant communities of engineering structures to be approximately in the same successional stage, we also chose structures that had been built 12 to 20 years prior to the study. We also ensured that the vegetation on site was not regularly managed.

\section{Environmental variables}

To control site homogeneity, several environmental variables were measured. Site coordinates and elevation were measured in situ using a high-accuracy GPS (GeoExplorer 6000, Trimble ${ }^{\circledR}$, California, USA), while river widths were measured using an Impulse 200 rangefinder (Laser Technology Inc., Colorado, USA). In the middle of each bank, steepness was also estimated using the same laser rangefinder for all main slope knickpoints located between the water level and the top of the bank. Measurements were later averaged to get a mean slope for each bank.

The construction date and effective length of structures were gathered from interviews. The Strahler rank of rivers (i.e. tributary hierarchy) as well as sites' aspect (northness) were retrieved from ArcGIS 10.7.1 (ESRI, 2019). We also used GISs to create two landscape-based categorical variables: context and stake. Context is a two-level factor describing the dominant landcover class in a $500 \mathrm{~m}$ radius around each site (i.e. mainly "semi-natural" or mainly "suburban"). Stake is a three-level factor stating what landscape feature or object is being protected by the structure: i.e. a "bridge" (road, railway etc.), an "urban area" (street, house etc.), or a "semi-natural area" (forest, pasture or crop). Finally, we derived climatic variables (i.e. mean annual temperature and annual sums of precipitation) from the WorldClim model (Hijmans et al., 2005) and adjusted for the effect of elevation following Zimmermann \& Kienast (1999).

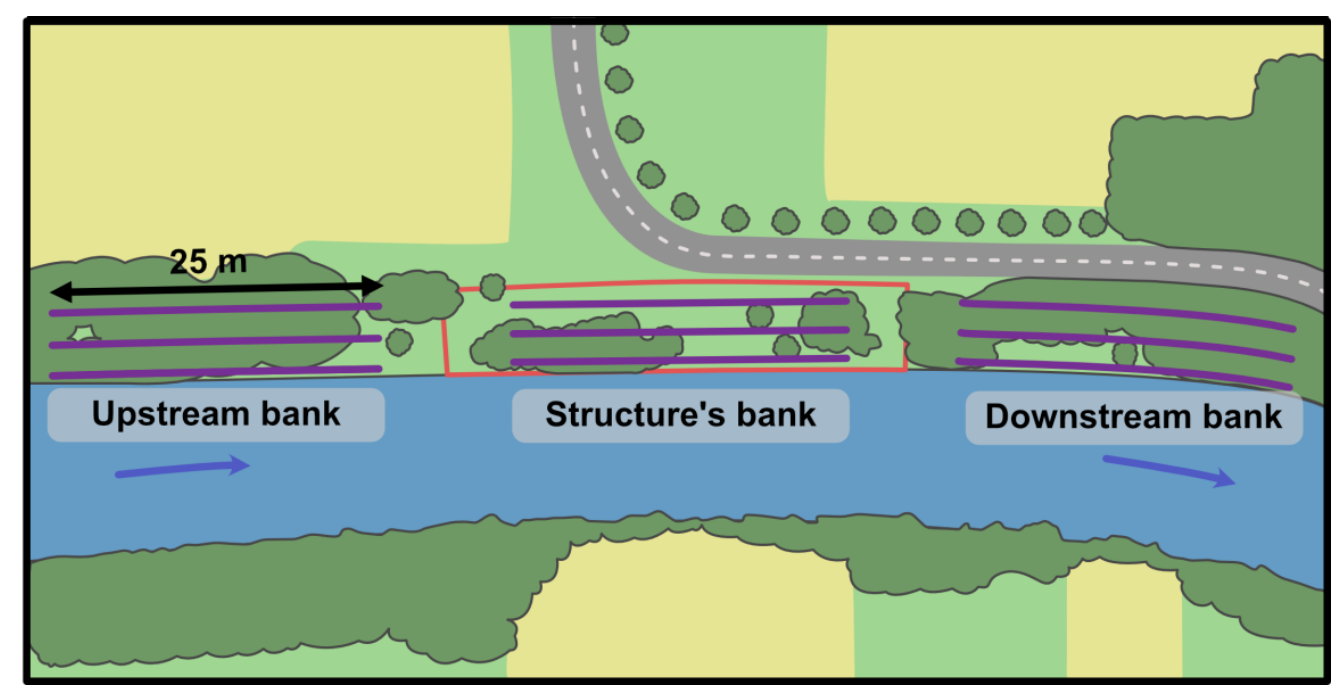


Fig. 1 Illustration of the sampling design of sites in an imaginary landscape mosaic. The red box indicates the location of the engineered embankment and purple lines represent sampling transects

\section{Vegetation survey}

Vegetation was surveyed using pin-point transects (Bonham, 2013). To sample the lateral gradient of riparian vegetation, we equidistantly placed three $25-\mathrm{m}$-long parallel transects alongside the river on the bottom, middle, and upper part of banks (Figure 1). Every $50 \mathrm{~cm}$ along each transect, a 2-m-long pole was vertically placed. If an individual of any plant species touched the pole below the height of $1 \mathrm{~m}$, it was recorded as belonging to the herbaceous stratum. If a plant actually or virtually touched the pole axis at a height of 1 to $5 \mathrm{~m}$, it was recorded as belonging to the shrub stratum, while any individual virtually crossing the pole axis at a higher height than $5 \mathrm{~m}$ was accounted for in the tree stratum. This method was chosen because it is time-efficient, robust against observer biases, and it gives good estimates of richness, abundance and cover for the most structuring plant species in the community (Buckland et al., 2007; Bonham, 2013). The status (i.e. native, alien, or invasive alien) of each plant species was subsequently retrieved from the official list of the French National History Museum (Gargominy et al., 2019). To summarize, we thus sampled 135 transects in total ( 3 transects per bank, 3 banks per site, 5 sites per type of engineering technique, 3 engineering techniques).

\section{Statistical analyses}

All analyses were performed using $R$ version 3.6.2 ( $R$ Development Core Team, 2019) and the 'vegan' (Oksanen et al., 2019) and 'stats' packages. Data exploration was performed following Zuur et al. (2010), and homoscedasticity was further checked using Bartlett tests.

Preliminary analyses were performed on environmental variables to assess whether fascine sites, mixed-technique sites and riprap sites were reasonably comparable (Online Resource 1). For quantitative variables (i.e. structure's age and length, river width and section's rank, site's latitude, longitude, elevation, slope, northness, average temperature and sums of precipitation), variations among the three groups of sites were investigated using either Kruskal-Wallis tests or Welch's ANOVAs, when data were homoscedastic or heteroscedastic, respectively (Sheskin, 2003; Jan \& Shieh, 2014). Dunn's or Games-Howell's tests for multiple comparisons were used when significant differences were found in the former and latter cases, respectively (Sheskin, 2003; Shingala \& Rajyaguru, 2015). The $p$-values of Dunn's tests were adjusted using the Holm-Bonferroni method. Mean slopes were additionally compared among the banks of each type of site to describe the topographical continuity of riverbanks. For the two categorical variables (namely context and stake), relationship among groups of sites and factor levels were examined using Pearson's Chisquare tests of independence (Sheskin, 2003).

To explore the floristic component of riparian connectivity, i.e. variation in riparian community composition among upstream bank, structure's bank and downstream bank, we used Non-Metric Multidimensional Scaling (NMDS) with Bray-Curtis distances (Legendre \& Legendre, 1998). First, highly uncommon species were removed based on sensitivity analyses ran to optimize NMDS stress values (Online Resource 2). Then, we performed a separate NMDS for each of the three groups of sites (i.e. fascine, mixed-technique and riprap) after ensuring the absence of multivariate spread in the data (Anderson, 2006). Within each group, we used Permutational Multivariate Analysis of Variance (PERMANOVA; cf. Anderson, 2017) with 999 permutations to test for 
significant differences in species composition between upstream, structure's and downstream banks. When significant differences were found, pairwise comparisons were then performed.

To understand the effects of stabilisation structures on biodiversity, we investigated variations in plant diversity patterns. Within each group of sites, overall plant richness (total number of species) and abundance (total number of species occurrences) were compared between the upstream, the structure and the downstream parts of riverbanks. Additionally, we also compared the richness and abundance of IAS (invasive alien plant species) using both absolute and relative measurements (i.e. proportions of IAS in total richness and abundance). Differences were investigated using Kruskal-Wallis tests or Welch's ANOVAs coupled with Dunn's or Games-Howell's post-hoc tests. To analyse the structural dimension of riparian vegetation connectivity, we used the same tests to highlight possible differences in herbaceous, shrub and tree cover within the three groups of sites.

\section{Results}

\section{Environmental variables}

Kruskal-Wallis tests and Welch's ANOVAs indicated that the three types of stabilisation structures (namely fascine, mixed-technique and riprap) were not located in similar environments. Mixedtechnique sites indeed appeared to be located along rivers with larger widths ( $p$-value $=0.015$ ) and Strahler ranks $(p$-value $=0.014)$ than the other two types of site. Their structure length also tended to present a marginally significant difference $(p$-value $=0.082)$. Structures also differed regarding mean slope $(p$-value $=0.022)$, with ripraps having significantly steeper slopes than fascine banks (adjusted $p$-value $=0.009$ ) and mixed-technique banks having intermediate values between these two extremes (for further details see Online Resource 1). Regarding the continuity of slopes within each type of site, no significant difference in mean bank slope was found for the fascine $(p$-value $=0.522)$ and mixed-technique sites $(p$-value $=0.41)$. However, a significant difference was found for riprap sites ( $p$-value $=0.017$ ). In these sites, upstream banks possessed milder bank slopes than both riprap (adjusted $p$-value $=0.021$ ) and downstream banks (adjusted $p$-value $=0.011$ ).

Chi-square tests also showed that the type of engineering structures was not randomly associated with context ( $p$-value $=0.005)$ or stake ( $p$-value $=0.016)$. Fascine sites were more often associated with semi-natural context and stakes, while the two other techniques appeared to be more frequently associated with suburban context and urbanized stakes such as bridges or urban areas (for further details see Online Resource 1).

\section{Plant community composition}

Across all sampled sites, a total of 295 plant species were found. All NMDS analyses gave satisfactory stress values $(<0.2)$ when 2 dimensions where kept, with a maximum value of 0.176 for the NMDS on mixed-technique sites and a minimum value of 0.094 for fascine sites. Overall, the only significant difference in species composition between upstream, structure and downstream banks was found for the fascine sites ( $p$-value $=0.004$; Figure 2 ). Pairwise comparisons indicated that the composition of fascine banks significantly differed from that of their downstream banks (adjusted $p$-value $=0.018$ ), but not from their upstream banks (adjusted $p$-value $=0.104$ ) (for further details see, Online Resource 2 ). 
Interestingly, among the 25 most abundant species on fascine banks, there was no IAS while there was two for the mixed-technique banks: i.e. Reynoutria spp and Solidago gigantea. In contrast, the 3 most abundant plant species on riprap banks were all IAS: i.e. Buddleia davidii, Reynoutria spp. and Parthenocissus quinquefolia.
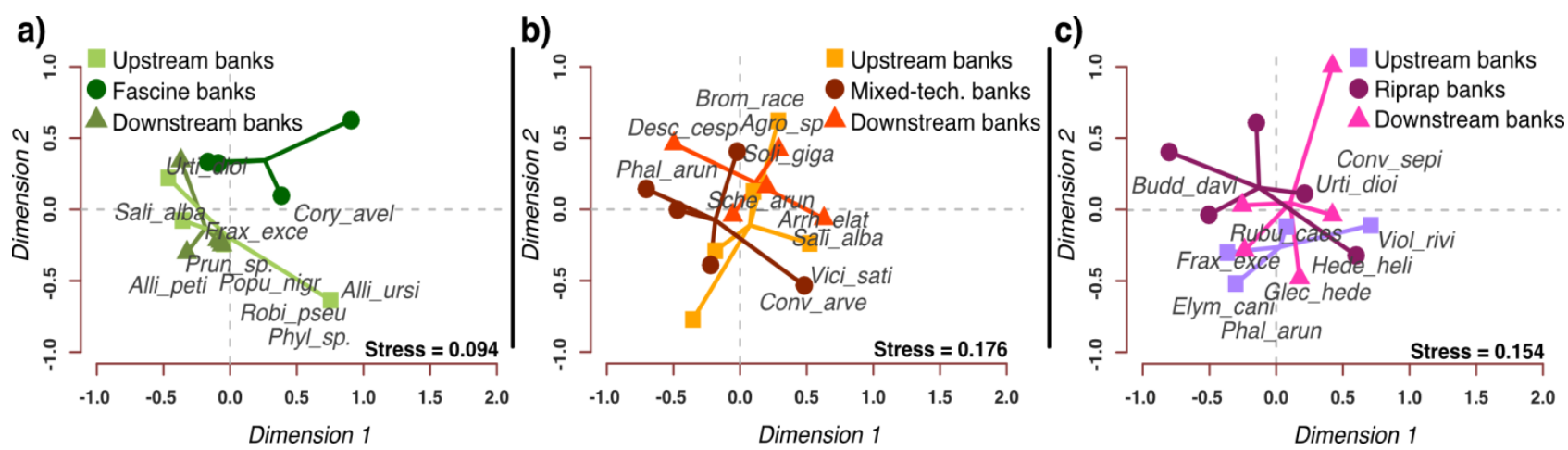

Fig. 2 NMDS ordinations of the floristic communities of upstream, structure's and downstream riverbanks in a) fascine sites, b) mixed-technique sites, and c) riprap sites. For each ordination, the stress value is given and the projections of the 10 species that are the most correlated with the NMDS dimensions (i.e. the most structuring species) are displayed. Abbreviations: Agro_sp $=$ Agrostis sp.; Alli_peti = Alliaria petiolata; Alli_ursi = Allium ursinum; Arrh_elat = Arrhenatherum elatius; Brom_race $=$ Bromus racemosus; Budd_davi $=$ Buddleia davidii; Conv_arve $=$ Convolvulus arvensis; Conv_sepi $=$ Convolvulus sepium; Cory_avel $=$ Corylus avellana; Desc_cesp $=$ Deschampsia cespitosa; Elym_cani $=$ Elymus caninus; Frax_exce $=$ Fraxinus excelsior; Glec_hede = Glechoma hederacea; Hede_heli = Hedera helix; Phal_arun = Phalaris arundinacea; Phyl_sp. = Phyllostachys sp.; Popu_nigr = Populus nigra; Prun_sp. = Prunus sp.; Robi_pseu = Robinia pseudoacacia; Rubu_caes $=$ Rubus caesus; Sali_alba = Salix alba; Sche_arun = Schedonorus arundinaceus; Soli_giga = Solidago gigantea; Urti_dioi = Urtica dioica; Vici_sati = Vicia sativa; Viol_rivi = Viola riviniana

\section{Diversity patterns and vegetation strata}

Regardless of the type of structure, no significant difference in total richness was found between upstream, structure and downstream banks (Figure 3a). A marginally significant difference in total abundance was however found among banks for mixed-technique sites ( $p$-value $=0.088$ ), and a significant difference was found among banks for riprap sites ( $p$-value $=0.04)$. Riprap banks indeed appeared to have a less abundant cover of plant species than their upstream banks (adjusted $p$ value $=0.025$ ), and marginally so than their downstream banks (adjusted $p$-value $=0.059$ ) .

Regarding IAS richness (absolute or relative), the only significant difference was found in fascine sites ( $p$-value $=0.032$ ), where downstream banks appeared to host a higher number of IAS than fascine banks (adjusted $p$-value $=0.022$; Figure $3 \mathrm{~b}$ ). Regarding IAS abundances however, two opposite patterns were found within fascine and riprap sites. Although differences were only marginally significant for IAS absolute abundances, significant differences in IAS relative abundances were found among fascine type $(p$-value $=0.048)$ and riprap type riverbanks ( $p$-value $=0.021$; Figure $3 \mathrm{~b}$ ). Fascine banks indeed displayed a lower IAS relative abundance than both their upstream (adjusted $p$-value $=0.033$ ) and downstream banks (adjusted $p$-value $=0.039$ ) . Conversely, riprap banks displayed a IAS relative abundance marginally higher than their upstream banks (adjusted $p$-value $=0.092$ ) and significantly higher than their downstream banks (adjusted $p$ value $=0.024)$. 

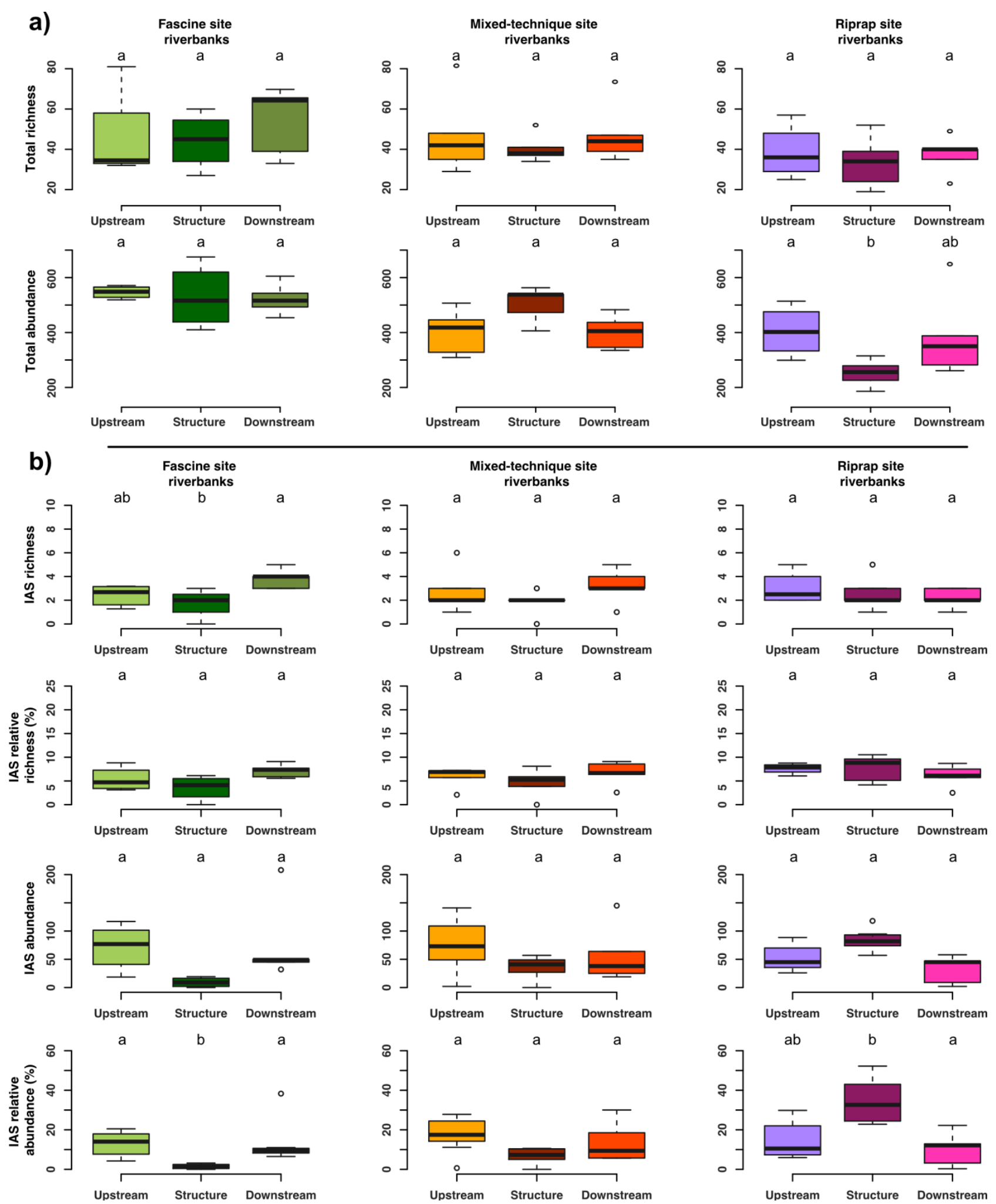

Fig. 3 Differences in (a) total plant species richness and abundance (total number of species occurrences), and (b) IAS absolute and relative (i.e. compared to total values) richness and abundances. Samples sharing the same letter are not significantly different

Overall, no significant differences in mean herbaceous, shrub and tree covers were found for any type of site (Figure 4). Nevertheless, a marginally significant difference in mean shrub cover in 
mixed-technique sites ( $p$-value $=0.093$ ) has been found, as well as for the mean tree cover of riprap sites ( $p$-value $=0.0511)$.
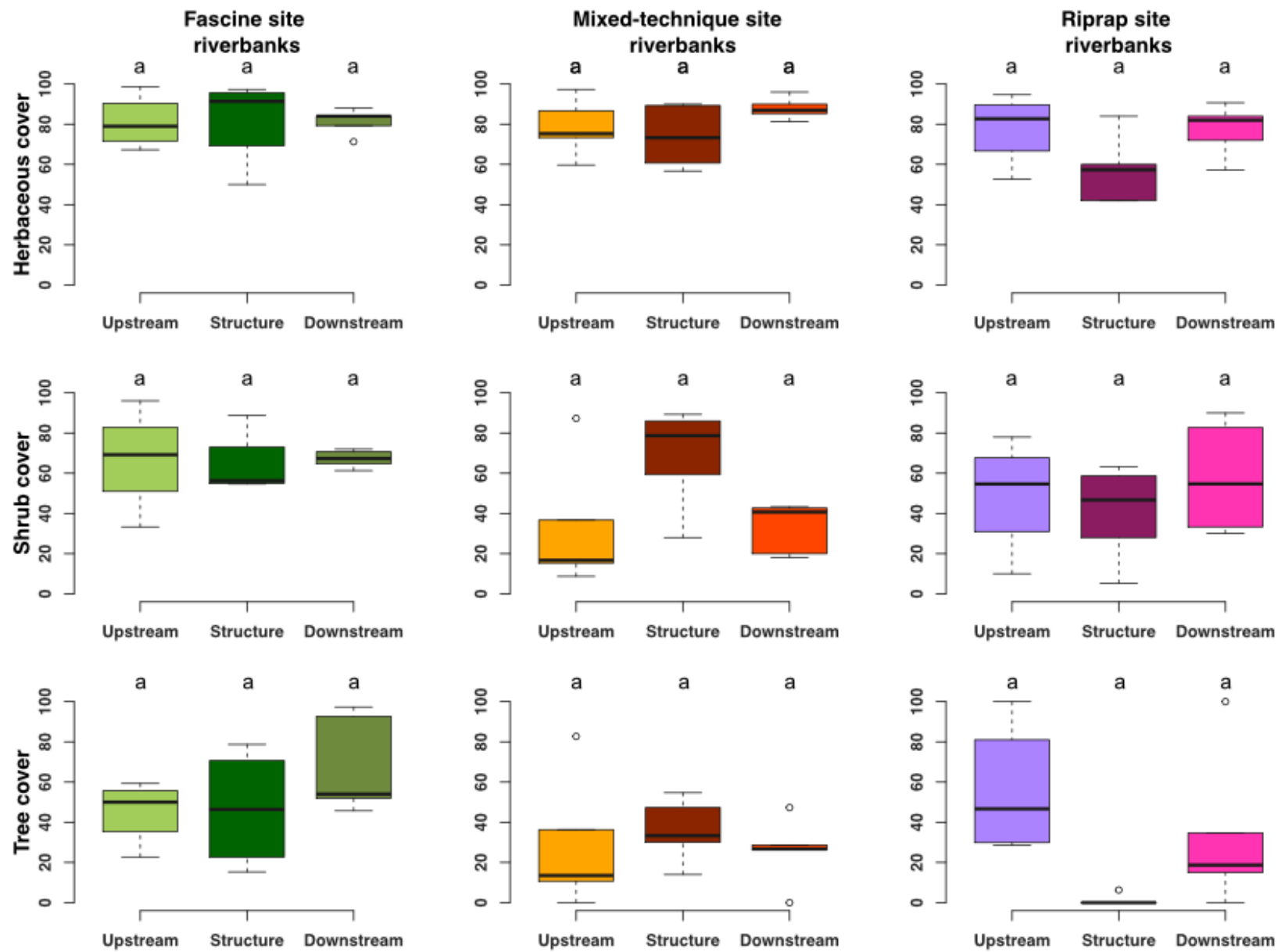

Fig. 4 Differences of cover of the different vegetation strata (herbaceous, shrub and tree). Samples sharing the same letter are not significantly different

\section{Discussion}

In this study, we examined the effects of three types of riverbank stabilisation structures (namely fascine, mixed-technique and riprap) on the compositional, diversity-related and structural continuity of riparian vegetation. Our results showed that, unlike ripraps, fascine banks displayed interesting features for restoring the structural connectivity of riparian vegetation, particularly in terms of vegetation cover and resistance against plant invasions. To a lesser extent, mixedtechnique banks also presented characteristics that could be beneficial for the riparian connectivity of the urbanized landscapes in which they are primarily located. These observations may be useful to improve the management of riparian corridors at the local and regional scales.

\section{Effects of stabilisation structures on the spatial continuity of riparian vegetation}

Our results indicated that soil bioengineering and civil engineering structures have different effects on the floristic component of riparian connectivity. On the one hand, fascine banks 
harboured plant communities that differed significantly from the communities of their downstream banks, and substantially from that of their upstream banks (Figure 2). Fascine banks also displayed significantly lower IAS absolute richness and relative abundance compared to their adjacent riverbanks (Figure $3 a, b$ ). These observations are likely related to the very nature of fascines, which are soil bioengineering structures that use a large amount of living plant materials. In our study area, lower parts of fascine banks were composed of live fascines (bundles of willow twigs) while willow cuttings were planted in upper parts. Fascines and cuttings consisted mostly of two willow species: Salix purpurea, S. viminalis. Other woody species, such as Corylus avellana or Cornus sanguinea, were also planted on the upper banks. Such profusion of fast-growing woody plants thus creates highly competitive assemblages that may filter out less adapted species (i.e. light demanding species), allowing the establishment of a different pool of herbaceous species between fascine structures and adjacent riverbanks. Furthermore, we showed that these competitive conditions seemed to constrain the richness and abundance of IAS. The most abundant IAS in the upstream and downstream banks of fascine sites were Reynoutria spp., Parthenocissus quinquefolia and Robinia pseudoacacia (Online Resource 2). On fascine banks however, competition for light and soil resources by planted native species likely reduced the vigour and spread of these IAS and enhanced the biotic resistance of the community (e.g. Byun et al., 2015; Dommanget et al., 2019). Fascine may thus potentially act as "sinks" for IAS propagules along riverbanks. On the other hand, if no differences in plant community composition were found for mixed-technique and riprap sites (Figure 2), riprap banks were far less abundantly covered by vegetation than their adjacent riverbanks (Figure 3a), and were significantly more dominated by IAS (Figure 3b). Ripraps are indeed known to be prone to invasions, both by terrestrial (Cavaillé et al., 2013) and aquatic species (Borcherding et al., 2011; Reid \& Church, 2015). They may thus potentially act as "sources" of IAS propagules within the longitudinal gradient of the river network.

Regarding the vegetation structure component of riparian connectivity, no significant differences between any of the compared riverbanks were highlighted. However, it is interesting to discuss some of the trends found in the dataset (Figure 4). While the vegetation structure of fascine banks tended to fit nicely in the continuity of their adjacent riverbanks, riprap banks seemed to possess lower herbaceous and especially tree covers than their upstream and downstream banks. Besides, mixed-technique banks appeared to present higher shrub cover than their adjacent riverbanks. The absence of statistical significance may simply be due to our limited sample size, with only 5 replicates for each type of engineered embankments. Indeed, these tendencies make sense: because of their mineral nature, ripraps often represent poor substrates subject to high temperature fluctuations, hence limiting the installation and survival of many native temperate species (Cavaillé et al., 2013; Aguilera et al., 2019). Consequently, ripraps usually represent harsh environment hosting lower specific and functional diversity as well as lower vegetation cover than natural or bioengineered embankments (Cavaillé et al., 2015; Reid \& Church, 2015; Janssen et al., 2019; Wollny et al., 2019). The lack of more significant differences in tree cover may additionally stem from the fact that the surrounding banks did not possess substantial tree covers themselves (Figure 4), as confirmed by preliminary analyses of environmental parameters showing that ripraps tends to be located in more urbanized environments (see Online Resource 1). As such, these stabilisation structures may represent degraded riparian habitats nested in a slightly less degraded continuum. A similar cause may explain the seemingly higher shrub cover of mixed-technique banks compared to their adjacent banks. This type of engineered embankment appeared to be mostly used in suburban areas characterized by relatively low covers of woody species. Since mixed-technique banks incorporate plantings of woody plant species, they may restore a certain level of shrub and tree covers amid 
segments of fragmented riparian corridors. This is in accordance with observations made in other settings (Cavaille et al., 2015), although the quality of the terrestrial and aquatic parts of such habitats has been criticized (Cavaillé et al., 2018; Janssen et al., 2019).

\section{Lessons for riparian corridors management}

The results presented in this study may be useful to inform stakeholders on one key aspect of the environmental impacts of engineering structures for riverbank stabilisation, namely structural connectivity, and help them decide which technique is most suited to reach their goals. Overall, we reckon that fascines are the structures with the lowest impact on the local structural continuity of riparian corridors. Although the floristic composition of fascine banks differs substantially from that of their adjacent riverbanks, which might affect the dispersal dynamics of some host-specific taxa (e.g. Menéndez \& Thomas, 2000), we argue that this drawback is quite counter-balanced by other features of fascine embankments. Fascines did not create discontinuities in the slope of riverbanks nor in the stratification of riparian vegetation which are very important elements for the population dynamics of many riparian species (Baguette \& Van Dyck, 2007; Fahrig, 2007; Gilbert-Norton et al., 2010) and the maintenance of most riparian ecosystem functions (Naiman \& Decamps, 1997; Wissmar \& Beschta, 1998; González Del Tánago \& García de Jalón, 2011; Gurnell, 2014). Moreover, the potential ability of fascine banks to constrain IAS richness and abundances is valuable for the habitat restoration function of engineered riverbanks (Li \& Eddleman, 2002; Cavaillé et al., 2013) as it means that fascine may enhance riparian connectivity without promoting the spread of IAS (cf. Richardson et al., 2007; Vilà \& Ibáñez, 2011).

Mixed-technique banks also exhibited interesting features since the only discontinuity they created in our study was the seemingly increase in shrub cover and total plant abundance of their riverbank section, although these differences lacked statistical significance. Yet, as pointed out by Janssen et al. (2019), the restoration value of this technique in terms of terrestrial and aquatic biodiversity is lower than that of pure soil bioengineering techniques, especially willow fascines. Incidentally, our results suggest that mixed-technique banks may have a lower potential to control IAS populations than fascines, possibly because the civil engineered part of their banks may be favourable to colonisation by Reynoutria spp. or Solidago gigantea, as observed in the studied riverbanks (Figure 2 and Online Resource 2). This civil engineered part possibly also explains the intermediate riverbank steepness that mixed-technique banks exhibited compared to fascine (mild slope) and riprap banks (steep slope; Online Resource 1). This is ecologically important since, for many species, steep slopes may represent dispersal barriers and may reduce longitudinal (Tabacchi et al., 1990; Richards-Zawacki, 2009) and lateral connectivity (Elosegi et al., 2010; Wollny et al., 2019).

Overall, ripraps appeared to be the most impacting technique for the structural connectivity of riverbanks. Compared to their adjacent riverbanks, ripraps tended to have lower vegetation covers, to be proportionally more dominated by IAS, and to exhibit steeper bank slopes. Previous studies partly using the same sites also showed that ripraps have lower woody vegetation cover, native species diversity, functional diversity, and higher IAS diversity than mixed-technique or fascine embankments (Cavaillé et al., 2013; Cavaillé et al., 2015). These observations suggest that ripraps may represent poor riparian habitats and corridors for many species. The fact that ripraps appeared to be mostly located in riverside suburban environments, i.e. in areas characterized by low woody vegetation cover and strong propagule pressure from IAS (Meek et al., 2010; Vilà \& Ibáñez, 2011), is not a relevant explanation for these differences since we compared ripraps with 
their adjacent riverbanks (and not explicitly with fascine or mixed-technique sites), and since mixed-technique sites were also located in suburban environments (Online Resource 1). Rather than satisfactorily explaining the lower ecological value of ripraps, their location in degraded environmental contexts may be viewed as a plea for favouring engineering techniques that fulfil ecological restoration functions on top of riverbanks stabilisation functions (e.g. Li et al., 2006; Rey et al., 2019). Avoiding a function of propagule source for downstream IAS invasions should be of special concern for riverine corridor management, particularly when stabilisation structures are meant to be located at the head of watersheds.

The ecological impacts and benefits of riverbank stabilisation structures are not the only aspects that matter for choosing an engineering technique for erosion control. Still, in cases where environmental considerations are important for stakeholders, evidence suggest that fascines should be preferred over the other techniques examined in this paper as they present highest ecological benefits in terms of habitat quality and continuity. Ripraps, on the other hand, seem to be quite poor habitats and may represent strong barriers possibly impeding the movement of many riparian species. Mixed-technique banks, with their intermediate position between these latter two techniques, should be favoured when ecological benefits are sought-after but banks require quick consolidation since ripraps provide immediate resistance against shear stress while the consolidation abilities of soil bioengineering techniques (e.g. fascines, cribwalls) increase over time (Pinto et al., 2016; Evette et al., 2018), simultaneously with their habitat quality (Janssen et al., 2019; Tisserand et al., 2020).

\section{Perspectives}

This study represents the first attempt to highlight the effects of riverbank stabilisation engineering structures on different components of the structural connectivity of riparian zones. However, other aspects of riparian connectivity still deserve attention to better enlighten management decisions, such as the aquatic components of riparian structure. Indeed, the continuity of aquatic habitats is likely to be affected by stabilisation structures as well (cf. Reid \& Church, 2015; Cavaillé et al., 2018). The edaphic component of riparian connectivity (or vertical connectivity) should also not be neglected because of its importance to explain longitudinal biodiversity patterns (Tabacchi et al., 1990; Tabacchi et al., 1998; Tickner et al., 2001). Similarly, the effects of stabilisation structures on the topographical continuity of riverbanks would deserve proper investigation and could be another stone in the garden of ripraps. The environmental characterisation of our study sites indeed showed that riprap was the only technique that disrupted the continuity of riverbank slopes (Online Resource 1). Another interesting perspective would be to extend such environmental impact assessment studies to incorporate the lateral dimension of riparian connectivity. The width of riparian corridors is indeed known to strongly influence species movements and assemblages (Lees \& Peres, 2008; Valle et al., 2013; Fremier et al., 2015). Consequently, continuities and discontinuities restored or induced by riverbank engineering structures are assumed to have distinct effects on biotic communities depending on the state and width of riparian corridors, as well as on the position of stabilisation structures along the river network (Swan \& Brown, 2017). Assessing the functional connectivity of riverbanks with engineered sections, with actual dispersal data or through network modelling, would also be a necessary step to quantify the direct impacts of stabilisation structures on the spatial dynamics of key species for conservation, such as umbrella species or protected species (e.g. Van Looy et al., 2013; Sutherland et al., 2015). Another informative research avenue would be to study people's 
perception of engineered embankments in the landscape, especially to assess whether it matches the ecological value of each structure (e.g. Zhao et al., 2017; Arsénio et al., 2019).

\section{Acknowledgement}

We are deeply grateful to Paul Cavaillé, Nathan Daumergue, Gilles Favier, Delphine Jaymond, Martin Fargeat and Timothée Herviault for their help at various stages of this work. We also thank Renaud Jaunatre for his helpful comments on the manuscript. This work was part of a project (Trame bleue : espaces et continuités) funded by the European Union through the European Regional Development Fund, the Auvergne-Rhône-Alpes region and the Agence de l'Eau RhôneMéditerranée-Corse.

The work in this study complied with current French legislation.

\section{References}

Aguilera M., Arias R., Manzur T., 2019. Mapping microhabitat thermal patterns in artificial breakwaters: Alteration of intertidal biodiversity by higher rock temperature. Ecology and Evolution, 9: 1-13.

Anderson M.J., 2006. Distance-based tests for homogeneity of multivariate dispersions. Biometrics, 62: 245-253.

Anderson M.J., 2017. Permutational Multivariate Analysis of Variance (PERMANOVA). In N. Balakrishnan, T. Colton, B. Everitt, W. Piegorsch, F. Ruggeri, \& J. Teugels (Eds.), Wiley StatsRef: Statistics Reference Online. John Wiley \& Sons, Ltd., Hoboken: USA (pp. 1-15).

Arsénio P., Rodríguez-González P.M., Bernez I., S. Dias F., Bugalho M.N., Dufour S., 2019. Riparian vegetation restoration: Does social perception reflect ecological value? River Research and Applications, n/a: 1-19.

Baguette M., Van Dyck H., 2007. Landscape connectivity and animal behavior: functional grain as a key determinant for dispersal. Landscape Ecology, 22: 1117-1129.

Beier P., Majka D.R., Spencer W., 2008. Forks in the road: Choices in procedures for designing wildland linkages. Conservation Biology, 22: 836-851.

Best J., 2019. Anthropogenic stresses on the world's big rivers. Nature Geoscience, 12: 7-21.

Bonham C.D., 2013. Measurements for terrestrial vegetation. John Wiley \& Sons, Chichester: The United Kingdom (246 p.).

Borcherding J., Staas S., Krüger S., Ondračková M., Šlapanský L., Jurajda P., 2011. Non-native Gobiid species in the lower River Rhine (Germany): recent range extensions and densities. Journal of Applied Ichthyology, 27: 153-155.

Buckland S.T., Borchers D.L., Johnston A., Henrys P.A., Marques T.A., 2007. Line transect methods for plant surveys. Biometrics, 63: 989-998.

Byun C., de Blois S., Brisson J., 2015. Interactions between abiotic constraint, propagule pressure, and biotic resistance regulate plant invasion. Oecologia, 178: 285-296.

Cavaillé P., Dommanget F., Daumergue N., Loucougaray G., Spiegelberger T., Tabacchi E., Evette A., 2013. Biodiversity assessment following a naturality gradient of riverbank protection structures in French prealps rivers. Ecological Engineering, 53: 23-30.

Cavaillé P., Ducasse L., Breton V., Dommanget F., Tabacchi E., Evette A., 2015. Functional and taxonomic plant diversity for riverbank protection works: bioengineering techniques close to natural banks and beyond hard engineering. Journal of Environmental Management, 151: 65-75. 
Cavaillé P., Dumont B., Van Looy K., Floury M., Tabacchi E., Evette A., 2018. Influence of riverbank stabilization techniques on taxonomic and functional macrobenthic communities. Hydrobiologia, 807: 19-35.

Dommanget F., Evette A., Breton V., Daumergue N., Forestier O., Poupart P., Martin F.-M., Navas M., 2019. Fast-growing willows significantly reduce invasive knotweed spread. Journal of Environmental Management, 231: 1-9.

Dudgeon D., Arthington A.H., Gessner M.O., Kawabata Z.-I., Knowler D.J., Lévêque C., Naiman R.J., Prieur-Richard A.-H., Soto D., Stiassny M.L.J., Sullivan C.A., 2006. Freshwater biodiversity: importance, threats, status and conservation challenges. Biological Reviews, 81: 163-182.

Elosegi A., Díez J., Mutz M., 2010. Effects of hydromorphological integrity on biodiversity and functioning of river ecosystems. Hydrobiologia, 657: 199-215.

ESRI, 2019. ArcGIS (v.10.7.1). Environmental Systems Resource Institute, Redlands (CA), USA.

Evette A., Labonne S., Rey F., Liebault F., Jancke O., Girel J., 2009. History of bioengineering techniques for erosion control in rivers in Western Europe. Environmental Management, 43: 972.

Evette A., Recking A., Piton G., Rauch H.P., Frossard P.A., Jaymond D., 2018. The limits of mechanical resistance in bioengineering for riverbank protection. IALCCE-2018, 6th International Symposium on Life-Cycle Civil Engineering. Ghent: Belgium (pp. 1-6).

Fahrig L., 2007. Non-optimal animal movement in human-altered landscapes. Functional ecology, 21: 1003-1015.

Fremier A.K., Kiparsky M., Gmur S., Aycrigg J., Craig R.K., Svancara L.K., Goble D.D., Cosens B., Davis F.W., Scott J.M., 2015. A riparian conservation network for ecological resilience. Biological Conservation, 191: 29-37.

Gargominy O., Tercerie S., Régnier C., Ramage T., Dupont P., Daszkiewicz P., Poncet L., 2019. TAXREF v13, référentiel taxonomique pour la France : méthodologie, mise en oeuvre et diffusion. Muséum national d'Histoire naturelle, Paris (France): 63 p.

Gilbert-Norton L., Watson R., Stevens J.R., Beard K.H., 2010. A meta-analytic review of corridor effectiveness. Conservation Biology, 24: 660-668.

Golfieri B., Surian N., Hardersen S., 2018. Towards a more comprehensive assessment of river corridor conditions: A comparison between the Morphological Quality Index and three biotic indices. Ecological Indicators, 84: 525-534.

González Del Tánago M., García de Jalón D., 2011. Riparian Quality Index (RQI): A methodology for characterising and assessing the environmental conditions of riparian zones. limnetica, 30: 0235-0254.

González E., Felipe-Lucia M.R., Bourgeois B., Boz B., Nilsson C., Palmer G., Sher A.A., 2017. Integrative conservation of riparian zones. Biological Conservation, 211: 20-29.

Gurnell A., 2014. Plants as river system engineers. Earth Surface Processes and Landforms, 39: 4-25.

Hijmans R.J., Cameron S.E., Parra J.L., Jones P.G., Jarvis A., 2005. Very high resolution interpolated climate surfaces for global land areas. International Journal of Climatology, 25: 1965-1978.

Jan S.L., Shieh G., 2014. Sample size determinations for Welch's test in one-way heteroscedastic ANOVA. British Journal of Mathematical and Statistical Psychology, 67: 7293.

Janssen P., Cavaillé P., Bray F., Evette A., 2019. Soil bioengineering techniques enhance riparian habitat quality and multi-taxonomic diversity in the foothills of the Alps and Jura Mountains. Ecological Engineering, 133: 1-9. 
Lambeets K., Vandegehuchte M.L., Maelfait J.-P., Bonte D., 2009. Integrating environmental conditions and functional life-history traits for riparian arthropod conservation planning. Biological Conservation, 142: 625-637.

Lavaine C., Evette A., Piégay H., 2015. European Tamaricaceae in bioengineering on dry soils. Environmental Management, 56: 221-232.

Lees A.C., Peres C.A., 2008. Conservation value of remnant riparian forest corridors of varying quality for Amazonian birds and mammals. Conservation Biology, 22: 439-449.

Legendre P., Legendre L., 1998. Numerical ecology. Elsevier, Amsterdam: The Netherlands (870 p.).

Li M.-H., Eddleman K.E., 2002. Biotechnical engineering as an alternative to traditional engineering methods: A biotechnical streambank stabilization design approach. Landscape and Urban Planning, 60: 225-242.

Li X., Zhang L., Zhang Z., 2006. Soil bioengineering and the ecological restoration of riverbanks at the Airport Town, Shanghai, China. Ecological Engineering, 26: 304-314.

Meek C.S., Richardson D.M., Mucina L., 2010. A river runs through it: Land-use and the composition of vegetation along a riparian corridor in the Cape Floristic Region, South Africa. Biological Conservation, 143: 156-164.

Menéndez R., Thomas C.D., 2000. Metapopulation structure depends on spatial scale in the host-specific moth Wheeleria spilodactylus (Lepidoptera: Pterophoridae). Journal of Animal Ecology, 69: 935-951.

Mitchell M.G., Bennett E.M., Gonzalez A., 2013. Linking landscape connectivity and ecosystem service provision: current knowledge and research gaps. Ecosystems, 16: 894-908.

Naiman R.J., Decamps H., 1997. The ecology of interfaces: Riparian zones. Annual Review of Ecology and Systematics, 28: 621-658.

Naiman R.J., Decamps H., Pollock M., 1993. The role of riparian corridors in maintaining regional biodiversity. Ecological Applications, 3: 209-212.

Oksanen J., Blanchet F.G., Friendly M., Kindt R., Legendre P., McGlinn D., Minchin P.R., O’Hara R., Simpson G.L., Solymos P., Stevens M.H.H., Szoecs E., Wagner H., 2019. Package 'vegan': Community ecology package (v.2.5-6). Vegan Development Team, https://github.com/vegandevs/vegan.

Pinto A.A.S., Fernandes L.F.S., de Oliveira Maia R.J.F., 2019. A method for selecting suitable technical solutions to support sustainable riverbank stabilisation. Area, 51: 285-298.

Pinto A.A.S., Fernandes L.F.S., Maia R., 2016. Monitoring methodology of interventions for riverbanks stabilization: Assessment of technical solutions performance. Water Resources Management, 30: 5281-5298.

Pyšek P., Bacher S., Chytrý M., Jarošík V., Wild J., Celesti-Grapow L., Gassó N., Kenis M., Lambdon P.W., Nentwig W., Pergl J., Roques A., Sádlo J., Solarz W., Vilà M., Hulme P.E., 2010. Contrasting patterns in the invasions of European terrestrial and freshwater habitats by alien plants, insects and vertebrates. Global ecology and biogeography, 19: 317-331.

R Development Core Team, 2019. R: A language and environment for statistical computing (v.3.6.2). R Foundation for Statistical Computing, Vienna: Austria.

Recking A., Piton G., Montabonnet L., Posi S., Evette A., 2019. Design of fascines for riverbank protection in alpine rivers: Insight from flume experiments. Ecological Engineering, 138: 323-333.

Reid D., Church M., 2015. Geomorphic and ecological consequences of riprap placement in river systems. Journal of the American Water Resources Association, 51: 1043-1059.

Rey F., Bifulco C., Bischetti G.B., Bourrier F., De Cesare G., Florineth F., Graf F., Marden M., Mickovski S.B., Phillips C., Peklo K., Poesen J., Polster D., Preti F., Rauch H.P., Raymond P., Sangalli P., Tardio G., Stokes A., 2019. Soil and water bioengineering: Practice and research 
needs for reconciling natural hazard control and ecological restoration. Science of the Total Environment, 648: 1210-1218.

Richards-Zawacki C.L., 2009. Effects of slope and riparian habitat connectivity on gene flow in an endangered Panamanian frog, Atelopus varius. Diversity and Distributions, 15: 796-806.

Richardson D.M., Holmes P.M., Esler K.J., Galatowitsch S.M., Stromberg J.C., Kirkman S.P., Pyšek P., Hobbs R.J., 2007. Riparian vegetation: degradation, alien plant invasions, and restoration prospects. Diversity and Distributions, 13: 126-139.

Scheffer M., Carpenter S., Foley J.A., Folke C., Walker B., 2001. Catastrophic shifts in ecosystems. Nature, 413: 591-596.

Sheskin D.J., 2003. Handbook of parametric and nonparametric statistical procedures: Third Edition. Chapman \& Hall/CRC, Boca Raton: USA (1184 p.).

Shingala M.C., Rajyaguru A., 2015. Comparison of post hoc tests for unequal variance. International Journal of New Technologies in Science and Engineering, 2: 22-33.

Sutherland C., Fuller A.K., Royle J.A., 2015. Modelling non-Euclidean movement and landscape connectivity in highly structured ecological networks. Methods in Ecology and Evolution, 6: 169-177.

Swan C.M., Brown B.L., 2017. Metacommunity theory meets restoration: isolation may mediate how ecological communities respond to stream restoration. Ecological Applications, 27: 2209-2219.

Tabacchi E., Correll D.L., Hauer R., Pinay G., Planty-Tabacchi A.-M., Wissmar R.C., 1998. Development, maintenance and role of riparian vegetation in the river landscape. Freshwater biology, 40: 497-516.

Tabacchi E., Planty-Tabacchi A.-M., Décamps 0., 1990. Continuity and discontinuity of the riparian vegetation along a fluvial corridor. Landscape Ecology, 5: 9-20.

Taylor P.D., Fahrig L., Henein K., Merriam G., 1993. Connectivity is a vital element of landscape structure. Oikos, 68: 571-573.

Tickner D.P., Angold P.G., Gurnell A.M., Mountford J.O., 2001. Riparian plant invasions: hydrogeomorphological control and ecological impacts. Progress in Physical Geography, 25: 22-52.

Tischendorf L., Fahrig L., 2000. On the usage and measurement of landscape connectivity. Oikos, 90: 7-19.

Tisserand M., Janssen P., Evette A., González E., Cavaillé P., Poulin M., 2020. Diversity and succession of riparian plant communities along riverbanks bioengineered for erosion control: a case study in the foothills of the Alps and the Jura Mountains. Ecological Engineering, in press.

Tockner K., Stanford J.A., 2002. Riverine flood plains: present state and future trends. Environmental Conservation, 29: 308-330.

Tonkin J.D., Merritt D.M., Olden J.D., Reynolds L.V., Lytle D.A., 2018. Flow regime alteration degrades ecological networks in riparian ecosystems. Nature Ecology \& Evolution, 2: 86-93.

Valle I., Buss D., Baptista D., 2013. The influence of connectivity in forest patches, and riparian vegetation width on stream macroinvertebrate fauna. Brazilian Journal of Biology, 73: 231238.

Van Looy K., Cavillon C., Tormos T., Piffady J., Landry P., Souchon Y., 2013. A scale-sensitive connectivity analysis to identify ecological networks and conservation value in river networks. Landscape Ecology, 28: 1239-1249.

Van Looy K., Honnay O., Pedroli B., Muller S., 2006. Order and disorder in the river continuum: the contribution of continuity and connectivity to floodplain meadow biodiversity. Journal of Biogeography, 33: 1615-1627.

Vilà M., Ibáñez I., 2011. Plant invasions in the landscape. Landscape Ecology, 26: 461-472. 
von der Thannen M., Hoerbinger S., Paratscha R., Smutny R., Lampalzer T., Strauss A., Rauch H.P., 2017. Development of an environmental life cycle assessment model for soil bioengineering constructions. European Journal of Environmental and Civil Engineering, 24: 141-155.

Ward J.V., Stanford J.A., 1995. Ecological connectivity in alluvial river ecosystems and its disruption by flow regulation. Regulated Rivers: Research \& Management, 11: 105-119.

Wissmar R.C., Beschta R.L., 1998. Restoration and management of riparian ecosystems: a catchment perspective. Freshwater biology, 40: 571-585.

Wollny J.T., Otte A., Harvolk-Schöning S., 2019. Dominance of competitors in riparian plant species composition along constructed banks of the German rivers Main and Danube. Ecological Engineering, 127: 324-337.

Zhao J., Wang R., Luo P., Xing L., Sun T., 2017. Visual ecology: exploring the relationships between ecological quality and aesthetic preference. Landscape and Ecological Engineering, 13: 107-118.

Zimmermann N.E., Kienast F., 1999. Predictive mapping of alpine grasslands in Switzerland: species versus community approach. Journal of Vegetation Science, 10: 469-482.

Zuur A.F., Ieno E.N., Elphick C.S., 2010. A protocol for data exploration to avoid common statistical problems. Methods in Ecology and Evolution, 1: 3-14. 